\title{
Ai Portugal, Portugal do que é que estás à espera??????
}

JO ÃO MÁRIO VASCONCELOS*

\section{Q erve este título para salientar o tempo perdido em medidas educa-} cionais avulsas, isto é, sem um estudo de referência com princípio meio e fim. Todos sabemos a grande iliteracia cientifica dos Portugueses e algumas das suas consequências na nossa sociedade. Podemos salientar, por exemplo, a área do ambiente onde os problemas são muitos e de alguma complexidade:

- ETAR's que não funcionam ou de funcionamento duvidoso,

- Aterros sanitários mal executados ou com deficiência diversas, sendo as mais graves relacionadas com a poluição de águas de superfície e até em algumas situações as águas profundas,

- Poluição industrial com influência directa nas águas das ribeiras e dos rios, desaguando alguns em albufeiras que são usadas em seguida para captação de água para abastecimento público,

- Traçado de estradas e construções de edifícios onde anteriormente havia cursos de águas,

- Uso de antibióticos indiscriminadamente em animais (vitelos, galinhas, perus, porcos) em quantidade e em qualidade que afectam a saúde pública,
Tudo isto num espaço europeu, onde a falta de técnicos com competência cientifica apropriada na área do ambiente é preocupante. Mas por cá está tudo bem! Acabou-se com o Curso Tecnológico de Ambiente e perspectiva-se outro de Ambiente e Ordenamento do Território sem qualquer disciplina de química. Eliminaram-se os cursos Tecnológicos de Química e de Mecânica e estavam na disposição de, nos cursos de Ciências e Tecnologias:

- Colocar as Ciências F/Q como opção no $10^{\circ}$ e 11 anos,

- Eliminar as Técnicas Laboratoriais de Química,

- Tirar a possibilidade a um aluno que queira seguir um curso superior, na área das ciências da saúde, de poder frequentar Química e Biologia em simultâneo. Noutros cursos, a Física e a Química não podem ser escolhidas em simultâneo,

- Sobrevalorizar as TIC.

Estas e outras situações perspectivadas para a reforma do Ensino Secundário, o tal "Novo Secundário", poderão levar ao caos do mesmo. Assim, depois do trabalho efectuado pela SPQ, através de várias reuniōes (Porto e Lisboa) e a colocação dos contributos e conclusões na página da internet da sociedade, há outros desafios pela frente. $E$ estes parecem-me muito mais importantes, uma vez que sou de opinião que as Sociedades Cientificas deveriam, já de algum tempo a esta parte, estar à frente do poder político. E, como? Poderemos perguntar.

Efectuando um estudo fundamentando para saber:

- quais as competências científicas

que os alunos Portugueses deveriam ter no final de cada ciclo de estudos (pré-escolar, $1^{\circ}, 2^{\circ}$ e $3^{\circ}$ ciclo, secundário e superior),

- quais as áreas onde são necessários recursos humanos.

A partir deste diagnóstico, elaborar uma proposta participada, objectiva, de uma revisão curricular interligada que vá ao encontro das necessidades reais e interesses do país.

Apelo a todos os Professores de Ciências e em particular de Física e Química todo o empenhamento, pois ou me engano muito ou os tempos que se avizinham serão preocupantes e vão requerer uma participação redobrada em todas as frentes.

Fevereiro de 2003 